\title{
Nutritional Composition and Antioxidant Analyses of Ageratum Conyzoides Whole Plant
}

\author{
Dauda J. Abiodun, Ameh E. Mark, Adaji M. Umar, Ocheme G. Wilson and Nayo R. Olufunke \\ Department of Pure and Industrial Chemistry, Kogi State University, Anyigba, Nigeria. \\ DOI: 10.29322/IJSRP.10.08.2020.p104115 \\ http://dx.doi.org/10.29322/IJSRP.10.08.2020.p104115
}

\begin{abstract}
The use of plants and their products for different purposes has been with man from the beginning. Aside food, plants are often used as medicine, an example of such plant is Ageratum conyzoides. This study was undertaken to evaluate the nutritional composition and antioxidant potency of Ageratum conyzoides whole plant. Ageratum conyzoides whole plant contained in percent, moisture $(5.52 \pm 0.035)$, ash $(10.47 \pm 0.058)$, crude protein $(24.53 \pm 0.104)$, crude lipid (3.78 \pm 0.069$)$, crude-fibre $(18.89 \pm 0.023)$ and carbohydrate $(36.81 \pm 0.006)$. Mineral analysis of the whole plant (in $\mathrm{mg} / \mathrm{l00g}$ ) revealed that the plant contained: Sodium (88.50 \pm 0.346$)$, Potassium (139.10 \pm 0.006$)$, Calcium (220.60 \pm 0.173$)$, Magnesium (110.13 \pm 0.115$)$, Iron (22.73 \pm 0.289$)$, Zinc (43.50 \pm 0.173$)$ and Phosphorus (380.13 \pm 0.173$)$. The result of proximate analyses showed that the whole plant is a good source of plant protein, minerals, crude fibre, and carbohydrate. If consumed in sufficient amount, it may contribute to mineral requirements for good health in human body. The qualitative screening for free radical scavenging compounds using 1,1Diphenyl-2-PicrylHydrazyl (DPPH) was carried out on TLC. The result showed greater activity in the n-hexane and ethanol extracts. In vitro quantitative determination of free radical scavenging activity using DPPH at 25, 50, 100, 200 and $400 \mu \mathrm{g} / \mathrm{mL}$ showed $\mathrm{n}$-hexane extract with the highest activity $\left(\mathrm{IC}_{50}\right.$ of $\left.45.34 \mu \mathrm{g} / \mathrm{mL}\right)$. The results of nutritional analyses showed that the whole plant is a good source of plant protein, minerals, crude fibre, carbohydrate and calories. If consumed in sufficient amount, it will contribute to nutritional requirements for good health in humans. Also the results obtained for antioxidant potentials have provided preliminary evidence for the use of Ageratum conyzoides in traditional medicine for the treatment of oxidative stress and free radicals.
\end{abstract}

Index Terms- Ageratum conyzoides, Antioxidant, Nutrient, Oxidative stress, Proximate

\section{INTRODUCTION}

$\mathrm{T}_{\mathrm{b}}$ he use of plants and their products for different purposes has been with man from the beginning. Aside food, plants are often used as medicine $[8,13,16]$. All plants produce chemical compounds as part of their normal metabolic activities. These can be divided into primary metabolites such as sugars and fats found in all plants and secondary metabolites such as alkaloids, flavonoids, tannins, saponins and phenols.

These secondary metabolites and other chemical constituents of medicinal plants account for their medicinal value
[7]. Medicinal plants often exhibit a wide range of biological and pharmacological activities such as; anti-inflammatory, antibacterial and anti-fungal properties. Extracts, syrups, infusions and concoctions prepared from different parts of plants are used to remedy different ailments. Such ailments include; typhoid, anaemia, malaria and headache [9]. In Nigeria many diseases were treated and are still being treated with medicinal plants with success. These diseases include malaria, epilepsy, infantile convulsion diarrhoea, dysentery, bacterial and fungal infections, mental illness, asthma, diabetes, worm infestation, pains and ulcers [17]. The efficacy of plants against ill health is possible, due to certain biologically active compounds such as nutrients and phytochemicals, which have physiological actions in the body of living organisms [9].

As various plant species are used either in the form of extract or decoction by the local people in different regions, therefore, evaluating their nutritional significance can help to understand the worth of these plants species [4]. The plant Ageratum conyzoides belongs to the family of Asteraceae. It is an erect, annual, branched, slender, hairy and aromatic plant which grows to approximately one meter in height. It is a native of Central America, Southeast Asia, South China, India and West Africa. It has been known since ancient times for its curative properties and has been utilized for the treatment of various ailments, such as burns and wounds, diabetes, headaches, pneumonia, inflammation, asthma, spasmodic and haemostatic diseases, stomach ailments, gynecological diseases, leprosy and other skin diseases [14]. The aim of this research is to evaluate the nutritional composition and antioxidant activity of Ageratum conyzoides whole plant.

\section{MATERIALS AND METHODS}

\section{Sample collection and Treatment}

Ageratum conyzoides plants were collected in July, 2019 from Dekina local government area of Kogi State, Nigeria. . Prior to analyses, the sample was identified at the Botany department, Kogi State University, Anyigba, Nigeria. The specimen voucher numbers is KSU.HSN-013/02/FM-038/CD-400. The sample was air dried and pulverized, it was then stored in a polythene bag to prevent moisture.

\section{Proximate Analysis}

Determination of proximate composition was carried out using the methods reported by the Association of Official Analytical Chemists [2]. Proximate composition of a substance 
constitutes the different classes of nutrients present in the samples such as carbohydrates, crude protein, crude fibre, crude lipid, ash content, moisture content and caloric value.

\section{Mineral Analysis}

The mineral content was determined according to the method described by [2]. Mineral elements ( $\mathrm{Ca}, \mathrm{Mg}, \mathrm{Zn}$ and $\mathrm{Fe}$ ) were determined using Atomic Absorption Spectrometry. After acid digestion of the plant, sodium and potassium were determined by Flame Emission Spectrometry. The phosphorus content was determined using Molybdate method with the aid of colorimeter.

\section{Preparation and Extraction of Plant Sample}

The whole plant was washed with clean water and air-dried under the shade for 14 days. It was ground to powder using wooden pestle and mortar. The powder was kept in moisture free container for further analysis. The powdered plant $(75 \mathrm{~g})$ was extracted sequentially with $600 \mathrm{~mL}$ each of n-hexane, acetone and ethanol using Soxhlet extractor for period of 3 hours. The percentage yields of the extracts were calculated.

\section{Qualitative Determination of Free Radical scavenging compounds using DPPH}

Freshly prepared DPPH solution $(0.00591 \mathrm{~g} \mathrm{DPPH}$ in $50 \mathrm{ml}$ methanol) was sprayed on freshly developed TLC plate of each extract. Formation of yellow or white $\operatorname{spot}(\mathrm{s})$ against purple background indicates the presence of free radical scavenging compound(s).

\section{Determination of in vitro Free Radical scavenging capacity using DPPH}

The free radical scavenging capacity of the extracts were tested against a solution of DPPH (DPPH in methanol) using the method reported by [3]. Various concentration of the extract were prepared in methanol $(25,50,100,200,400 \mu \mathrm{g} / \mathrm{ml})$. The samples of the different concentration were mixed with $2 \mathrm{~mL}$ of the prepared DPPH. The mixture was shaken vigorously and allowed to stand in the dark at room temperature for 20 minutes. The absorbance was measured at $517 \mathrm{~nm}$ using UV-Visible Spectrophotometer for both samples and blank. Ascorbic acid (Vitamin C) at various concentrations was used as standard. Inhibition of free radical scavenging activity by DPPH in percent (I \%) was calculated using the equation below:

$$
\% I=\left\{\left(A_{\text {blank }}-A_{\text {sample }}\right) / A_{\text {blank }}\right\} \times 100
$$

\section{RESULTS AND DISCUSSION}

\section{plant)}

Proximate Composition of Ageratum conyzoides (whole

The proximate composition of the plant (Table 1 and Figure 1) shows low moisture content. This is of great importance, since high moisture is associated with increase in microbial activities during storage [10]. The ash content of the plant $(11.78 \pm 0.03 \%)$, which represents the index of mineral elements present in the plant. The value obtained for the ash showed that the plant contained considerable amounts of inorganic elements. The crude protein content of the whole plant (Ageratum conyzoides) was found to be $24.53 \pm 0.104 \%$. The value obtained was higher when compared with the value obtained for the leaf and root $(14.73 \%)$ and $(9.89 \%)$ respectively as reported by [1]. This implies that the whole plant can serve as a good source of protein supplements. The crude fibre content of the whole plant is18.89 $\pm 0.023 \%$. The value obtained was low when compared with the value obtained for the leaf and root $(23.50 \%)$ and $(26.74 \%)$ respectively as reported by [1]. This value fall within the recommended age $12-$ $38 \mathrm{~g} /$ day depending on the age and sex [6]. Fibre diet promote the wave-like contraction that move food through the intestine, high fibre in food expands the wall of colon, easing the passage of waste. Fibre diet also lower cholesterol level in the blood, reduce risks of various cancers, blood diseases and improve general health and wellbeing of man [15]. The available carbohydrate content of the plant was found to be $36.81 \pm 0.006 \%$. The value obtained is in close range when compared with the values reported by [1] for the leaf and root (36.84\%) and (31.06\%) respectively. This shows that the plant can also serve as a good source of carbohydrate and calories. Carbohydrate is an essential part of food because; it is the major storage substance in seeds of most cultivated plants and also, the main source of energy for human body [5].

Table 1: Proximate composition of Ageratum conyzoides.

\begin{tabular}{|c|c|c|}
\hline Parameters & \multicolumn{2}{|c|}{$\begin{array}{l}\text { A. Conyzoides } \\
\text { palnt) }\end{array}$} \\
\hline IV. MOISTURE (\% DW) & XI. & $5.52 \pm 0.035$ \\
\hline V. $\operatorname{AsH}(\% \mathrm{DW})$ & XII. & $10.47 \pm 0.058$ \\
\hline $\begin{array}{c}\text { VI. CRUDE PROTEIN ( } \% \\
\text { DW) }\end{array}$ & XIII. & $24.53 \pm 0.104$ \\
\hline $\begin{array}{c}\text { VII. CRUDE FIBRE (\% } \\
\text { DW) }\end{array}$ & XIV. & $18.89 \pm 0.023$ \\
\hline $\begin{array}{c}\text { VIII. CRUDE LIPID (\% } \\
\text { DW })\end{array}$ & XVI. & $36.81 \pm 0.006$ \\
\hline $\begin{array}{c}\text { IX. CARbohydrate } \\
(\% \text { DW })\end{array}$ & XVII. & $1168.80 \pm 0.006$ \\
\hline $\begin{array}{c}\text { X. Calorificvalue } \\
(\mathrm{KCAL} / 100 \mathrm{G})\end{array}$ & & \\
\hline
\end{tabular}


Values are mean \pm SE of three replicates

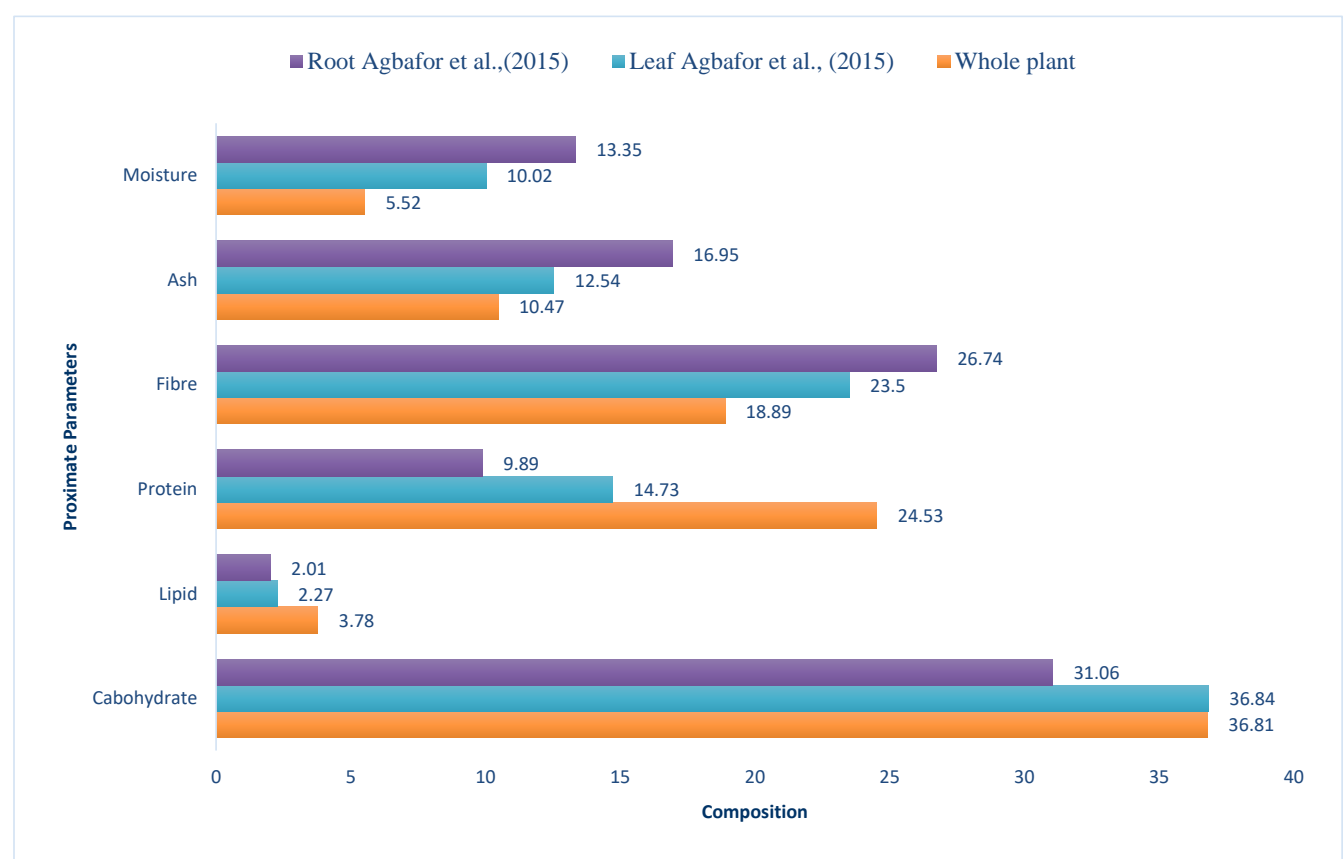

Figure 1: The proximate composition value of Ageratum conyzoides

\section{Mineral Analysis of Ageratum conyzoides (whole plant)}

The results of mineral composition (Table 2 and Figure 2) revealed that phosphorus is the most abundant in the whole plant ( $380.13 \mathrm{mg} / 100 \mathrm{~g}$ ), followed by calcium, potassium, magnesium, sodium, zinc and iron, with the values in $\mathrm{mg} / 100 \mathrm{~g}$ of 220.60 , $139.10,110.13,88.50,43.50$ and 22.73 respectively. The values are higher when compared with the values reported by [1] for the leaf and root, except for sodium (Figure 2). Concentrations of the mineral elements in the whole plant are low when considering the recommended daily allowance, except for zinc and iron [11]. Although the concentration of some mineral elements is low, however, the whole plant is still a good source of mineral elements.
Table 2: Mineral composition of Ageratum conyzoides whole plant

\begin{tabular}{lll}
\hline Minerals & Concentration $(\mathbf{m g} / \mathbf{1 0 0}$ g) \\
\hline Sodium & $88.50 \pm 0.346$ & \\
Potassium & $139.10 \pm 0.006$ & \\
Calcium & $220.60 \pm 0.173$ & \\
Phosphorus & $380.13 \pm 0.115$ & \\
Magnesium & $110.13 \pm 0.115$ & \\
Iron & $22.73 \pm 0.289$ & \\
Zinc & $43.50 \pm 0.173$ & mean \pm
\end{tabular}

SE of three replicates 


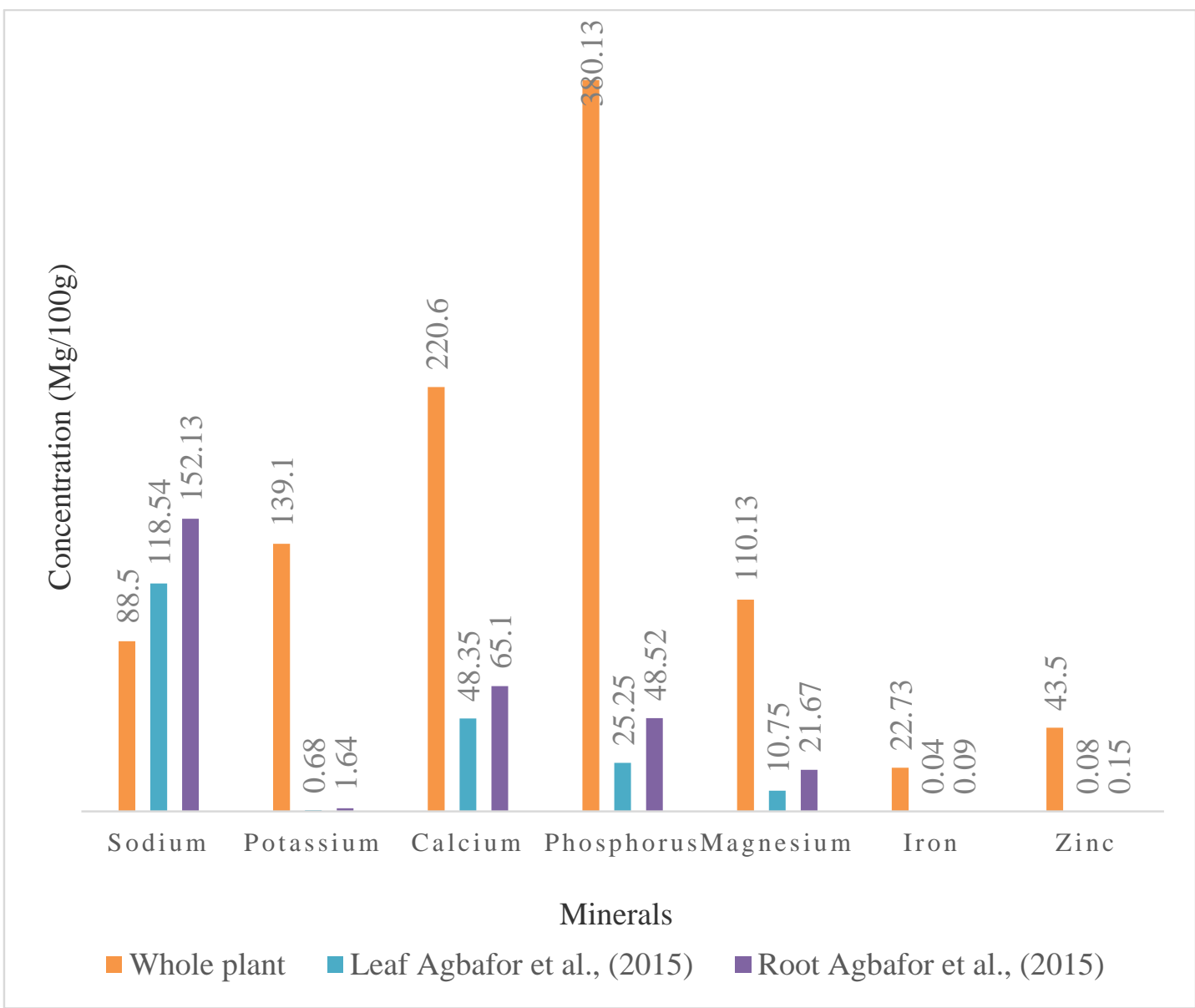

Figure 2: Mineral composition of Ageratum conyzoides

\section{Qualitative free radical Scavenging Activity on DPPH}

The presence of free radical scavenging compounds of the whole plant was observed in the n-hexane, acetone and ethanol extracts. However, a different degree of free radical scavenging activity was observed from the TLC plates (Table 3, Plates 1, 2 and 3). [12] reported that free radical scavenging compounds show yellow or white spots on the TLC plate. The n-hexane and ethanol extracts shows high potency as shown on the TLC plate.
Table 3: Qualitative free radical scavenging activity on DPPH

\begin{tabular}{ll}
\hline Extracts & Inference \\
\hline Acetone & + \\
n-Hexane & +++ \\
Ethanol & +++ \\
\hline
\end{tabular}

Key: $+=$ slightly active; $+++=$ highly active

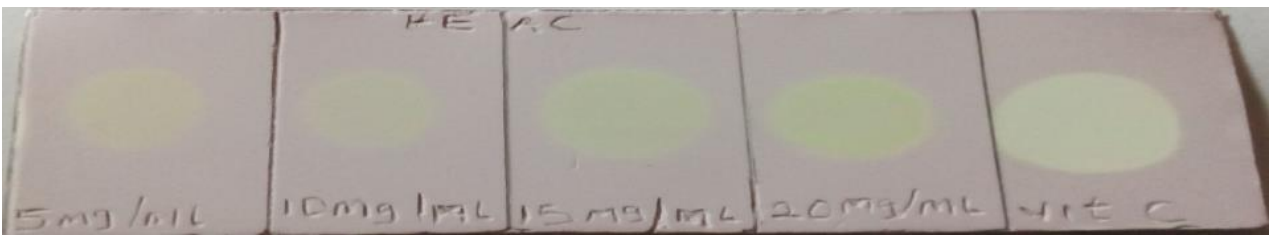

Plate 1: n-Hexane extract

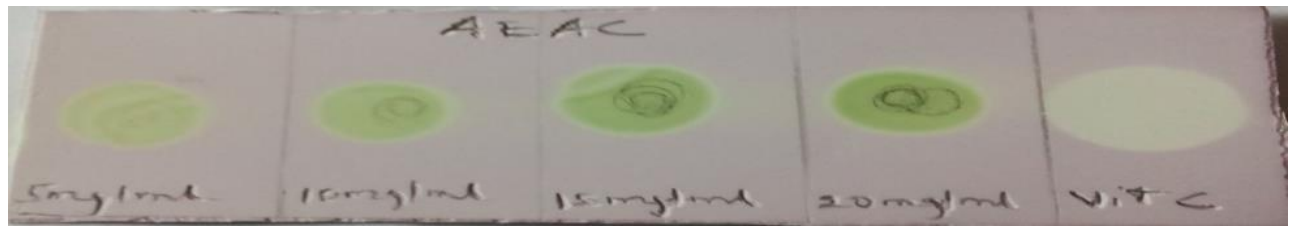


Plate 2: Acetone extract

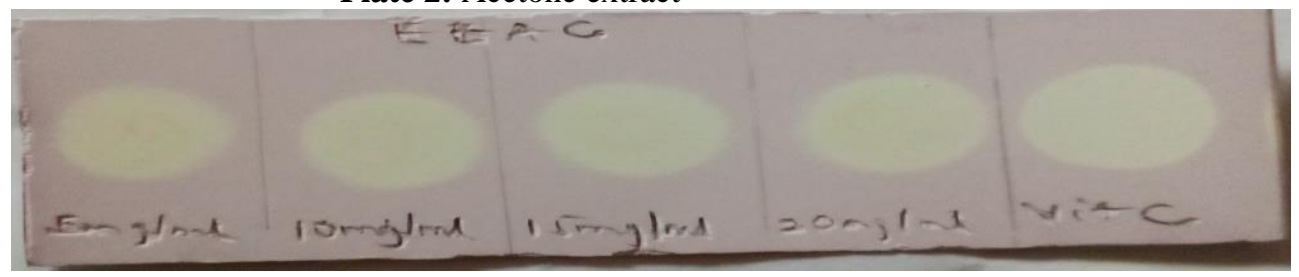

Plate 3: Ethanol extract

Figure 3: Qualitative analysis of free radical scavenging activity on DPPH.

Quantitative free radical scavenging activity using DPPH

The quantitative free radical scavenging activity of the whole plant (Table 4 and Figure 4), revealed that, the free radical scavenging potential of the extracts are concentration dependent. The n-hexane extract demonstrated the highest free radical scavenging potential (at $400 \mu \mathrm{g} / \mathrm{mL}$ ) when compared with the other extracts. On the other hand, the acetone extract shows significant activity (at $400 \mu \mathrm{g} / \mathrm{mL}$ ) when compared with the ethanol extract. The $\mathrm{IC}_{50}$ values revealed $\mathrm{n}$-hexane extract to be more potent than the other extracts. N-hexane extract had $\mathrm{IC}_{50}$ value of $45.34 \mu \mathrm{g} / \mathrm{mL}$ (Table 5). The lower the $\mathrm{IC}_{50}$ value the more potent is the extract.

Table 4: Quantitative analysis of Free radical scavenging activity using DPPH

\begin{tabular}{lcllll}
\hline \multirow{2}{*}{ S/N } & $\begin{array}{c}\text { Concentration } \\
(\mu \mathrm{g} / \mathbf{m L})\end{array}$ & $\begin{array}{l}\text { Zone of inhibition (\%) } \\
\text { n-Hexane }\end{array}$ & $\begin{array}{l}\text { Acetone } \\
\text { Extract }\end{array}$ & $\begin{array}{l}\text { Ethanol } \\
\text { Extract }\end{array}$ & $\begin{array}{l}\text { Ascorbic } \\
\text { acid }\end{array}$ \\
\hline 1 & 25 & $2.5 \pm 0.5$ & $9.8 \pm 0.3$ & $16.5 \pm 0.5$ & $86.5 \pm 0.5$ \\
2 & 50 & $10.5 \pm 0.5$ & $24.8 \pm 0.3$ & $20.6 \pm 0.3$ & $87.5 \pm 0.5$ \\
3 & 100 & $14.3 \pm 0.8$ & $28.5 \pm 0.5$ & $24.5 \pm 0.5$ & $87.5 \pm 0.5$ \\
4 & 200 & $45.3 \pm 0.8$ & $33.8 \pm 0.3$ & $28.8 \pm 0.3$ & $88.5 \pm 0.5$ \\
5 & 400 & $48.5 \pm 0.5$ & $39.5 \pm 0.5$ & $34.8 \pm 0.3$ & $99.5 \pm 0.5$ \\
\hline
\end{tabular}

Table 5: $\mathrm{IC}_{50}$ Values of the extracts

\begin{tabular}{ll}
\hline Extracts & $\mathrm{IC}_{50}$ \\
\hline Acetone & 56.66 \\
Ethanol & 54.93 \\
n-Hexane & 45.34 \\
Ascorbic acid & 12.29 \\
\hline
\end{tabular}




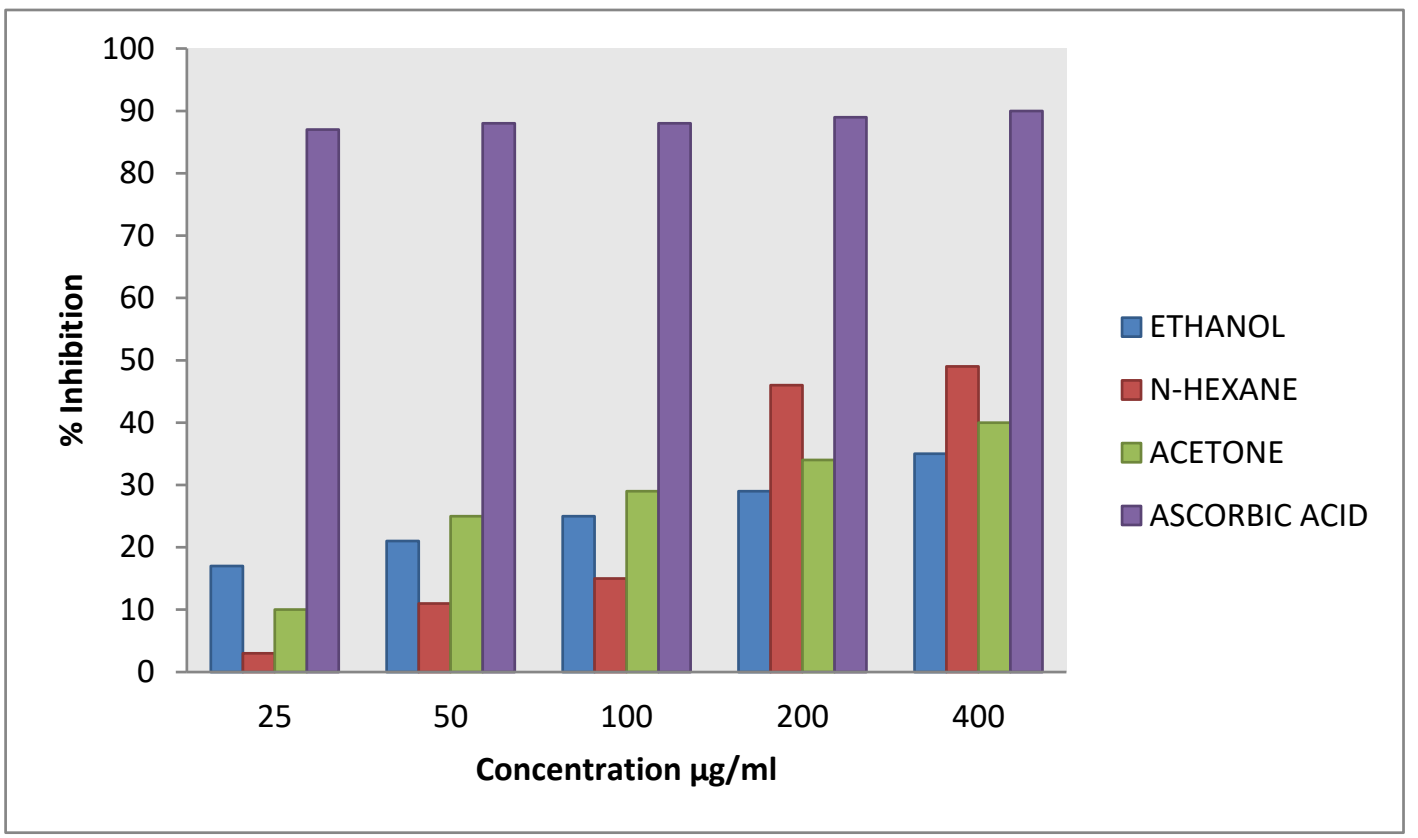

Figure 4: Showing the Free Radical Scavenging activity of Ageratum conyzoides

\section{CONCLUSION}

The results of this study revealed that the whole plant of Ageratum conyzoides is a good source of plant protein, minerals, crude fibres, carbohydrate and calories. Therefore, if consumed in sufficient amount, the whole plant will contribute to nutritional requirements for good health in humans. However, there is need for toxicological studies to affirm the above statement. The extracts also demonstrated antioxidant activities with n-hexane extract showing the highest potency.

\section{REFERENCES}

[1] Agbafor, K. N., Engwa, A. G. and I. K. Obiudu, I. K., (2015). Analysis of Chemical Composition of Leaves and Roots of Ageratum conyzoides: review of International Journal of Current Research and Academic review; ISSN: 2347-3215. 3(11): pp. 60-65.

[2] Association of Analytical Chemists (AOAC), (2010). Official Methods of Analysis.16th edition, 4th Revision. Washington D. C. USA. 1121-1180.

[3] Adesegun, S. A., Elech, N. A., Coker, N. A. and H. A. B. (2008). Antioxidant activity of methanolic extract of sapiumellioticum. Pakistan Journal of biological sciences, 11: 453-457

[4] Adnan, M., Hussain, J., Tahir Shah, M., Shinwari, Z. K., Ullah, F., Bahader, A. and Watanabe,T. (2010). Proximate and nutrient composition of medicinal plants of humid and sub-humid regions in North-west Pakistan. Journal of Medicinal Plants Research, 4(4): 339-345.

[5] Carpi, A. (2003). Carbohydrate. 'Vision learning'. CHE 2 (5): Retrieved from http://www.visionlearning.com/library/moduleviewer.php?mid=61. Retrieved on 17/09/2019.

[6] Copeland, L. O. (1976). Principles of Seed Science and Technology, Burgerss Publishing Company, Michigan. Pp 37-51.

[7] Daniel, M. (2016). Medicinal plants: chemistry and properties. E-Book-PDF. (13; 978-4279-9), CRC press.

[8] Devendran, G. and Balasubramanian, U. (2011).Qualitative Phytochemical Screening and Gc-Ms analysis of Ocimum sanctum L.leaves. Asian Journal of Plant Science and Research; 1(4): 44ᄀ-48.
[9] Edeoga, H. O., Okwu, D. E. and Mbaebie, B. O. (2005). Phytochemical constituents of some Nigerian medicinal plants. African Journal of Biotechnology, 4 (7): 685-688.

[10] Enujiugha, U. N. and Akanbi, C. T. (2005). Compositional changes in Africa oil bean seeds during thermal processing. Pakistan Journal of Nutrition. 4(1): 27-31

[11] FND, (2002). Food and Nutritional Board, Institute of Medicine. National Academy of Sciences. Dietary Reference intake for Energy, Carbohydrate, Fibre, Fat, Fatty acids, Cholesterol, Protein and Amino acids (Micronutrients). Retrieved on 30th April, 2019 from www.nap.edu. Pp 2351.

[12] Halilu, M. E., Akpulu, I. K., Agunu, A., Ahmed, A. and Abdurahman, E. M (2008). Evaluation of Parinari curatetellifolia Planch Ex Benth (Chrysobalanaceae), Nigerian Journal of Basic and Applied Sciences. 16(2): 281-285.

[13] Iwu, M. M. and Gbodossou, E. (2000). The role of traditional medicine. The Lancet, 356, S3.

[14] Kamboj, A. and Saluja, A. K. (2008). Ageratum conyzoides L.: A review on its phytochemical and pharmacological profile. International Journal of Green Pharmacy (IJGP), 2 (2): 59-68.

[15] Kang, J. (2013). Digestion and absorption. In Nutrition and Metabolism in Sports, Exercise and Health. Routledge. Pp150-175.

[16] Ogunkunle, A. T. J. and Ladejobi, T. A. (2006). Ethnobotanical and phytochemical studies on some species of Senna in Nigeria. African Journal of Biotechnology, 5 (21): 2020-2023.

[17] Papadakis, M. A. and McPhee, S. J. (2019). Current medical diagnosis and treatment. McGraw-Hill. Retrieved from http://thuvienso.Vanlanguni.edu.vn/handle/Vanlang-TV/13425.

\section{AUTHORS}

First Author - Dauda J. Abiodun, (M.Sc, B.Sc)

Kogi State University, Anyigba, Nigeria daudajoseph@kogistateuniversity.edu.ng

Second Author - Ameh E. Mark, (PhD, M.Sc, B.Sc)

Kogi State University, Anyigba, Nigeria

markameh2004@yahoo.com

Third Author - Adaji M. Umar (M.Sc, B.Sc)

This publication is licensed under Creative Commons Attribution CC BY. 
Kogi State University, Anyigba, Nigeria adajimed@gmail.com

Fourth Author-Ocheme G. Wilson (M.Sc, B.Sc)

Kogi State University, Anyigba, Nigeria,

merit4luck@yahoo.com
Correspondence Author - Dauda J. Abiodun

daudajoseph@kogistateuniversity.edu.ng

anonymouslincon@gmail.com, +2348062422941, $+2348129624175$ 